ISBN / 978-93-5137-179-3

ISSN

$2320-7329$

Ayurlog: National Journal of Research in Ayurved Science

\title{
Innermost reconciliation through vipassana
}

\section{Shweta C. Khade**1, Archana Gharge*²}

1. MD. Scholar Roganidan department

2. HOD \& professor Roganidan department

Y.M.T. Ayurvedic Medical College Kharghar, Navi Mumbai.

*Corresponding Author khadeshweta.sk11@ gmail.com; Mob.no. - 8600164743

\section{Abstract:}

Health is described by the word swasth in Sanskrit which mean to be established in the self. Health is really moment to moment awareness and this can be obtained through meditation.

Reconciliation means to restore to compatibility or harmony and to restore sacred. while practicing reconciliation, we are reconcile our self to the truth that in this movement, there are painful differences or polarities between you and another and rather allowing your heart to become closed to the another it tremendous cost to your wellbeing, it draining your energy in hopeless demands that what has already happened or not to be true.

Vipassana is word in pali language translated as "Insight a clear awareness of exactly what is happening as it happens. Vipassana is direct and gradual cultivation of mindfulness or awareness. Main effect of the practice is that we get deep understanding about the nature of our self. It brings inner peace ultimately restore compatibility or harmony.

KEYWORD: Swasth, Reconciliation, Vipassana, Harmony 


\section{INTRODUTION:}

Health is described by the Sanskrit word Swastha which means 'Swa'=Established of health in self and 'Tha' = its stability. According to WHO health is defined.

According to Ayurveda Swasth is Defined as

\section{सम:दोषा: समाग्रिश्चः समधातु मलक्रिय: । प्रसत्रात्मेन्द्रिय मन: इत्याभिधियते।}

To obtain good health \& its preservation we need to a innermost reconciliation it mean to restore to compatibility or harmony and to restore sacred. while practicing reconciliation, we are reconciled our self to the truth that in this movement, there are painful differences or polarities between we and another and rather allowing our heart to become closed to the another it tremendous cost to our wellbeing, it draining our energy in hopeless demands that what has already happened or not to be true.

Vipassana is word in pali language translated as "Insight a clear awareness of exactly what is happening as it happens. Vipassana is direct and gradual cultivation of mindfulness or awareness. Main effect of the practice is that we get deep understanding about the nature of our self. It brings inner peace ultimately restore compatibility or harmony. Which is important for swasth.

\section{Aim \& Objectives :}

1. Conceptual study of Reconciliation through Vipassana.

2. Review of Ayurvedic literature and scholar article regarding.

\section{Materials :}

- Charak Samhita

- Sushrut Samhita

- Ayurvedic journals and published Articles.
Method: Type of study - Conceptual study (Review article )

\section{Literature Review:}

\section{RECONCILIATION:}

Reconciliation means to restore to compatibility or harmony and to restore the sacred. It is also defined as "to make consistent or congruent" for example, to reconcile our ideals with reality. When we practice reconciliation, we are reconciling our self to the truth that in this moment there are painful differences or polarities between us and another, and rather than allowing our heart to become closed to the other, we are seeking to align the $\mathrm{mind} /$ heart to include them just as they are.

There is a tremendous cost to our wellbeing when we shut our heart to others. On the most practical level, being shut down by anger or hate is not an effective position for working toward change. It breeds a feeling of despair, of victimhood, and what is called "learned helplessness." Refusing to reconcile to the way things are also means we are draining our energy in a hopeless demand that what has already happened not be true. One teacher put it this way: "Do not hope for a better past." Finally, closing our heart to others to keep from having

to admit to ourself that you, like all other humans, are capable of unskilful behaviour prevents you from feeling own emotions.

\section{How to Practice Reconciliation}

Reconciliation practice is the aligning and softening of the heart to be reconciled with this moment just as it is. It doesn't involve resignation or defeat. Instead, it is a way to embrace the entirety of our experience, in which nothing is left out not even the things we think our selflives with. When we don't separate our self from parts of our experience, we have more access both to your wisdom and to your deepest 
values, and therefore your actions tend to be more skilful.

To experience reconciliation, we must acknowledge the truth that there are substantial differences between us and another. A successful reconciliation is not contingent on the disappearance of those differences, and it certainly does not imply that you will become best friends with everyone else.

Rather, the intention to be reconciled is the wish to be connected to the sacred oneness of this moment despite any differences and to find harmony within any situation, even the painful.

\section{Accept the Truth}

Reconciliation is not an endpoint of practice. It is a beginning place for continuing to free our heart. Through reconciliation, you gain momentum toward lovingkindness an unconditional wellwishing that flows freely from the unencumbered heart, independent of conditions.

It is worth remembering that the Buddha admonished us not to cling to our views and that hatred never conquers hatred. May you be reconciled with those with whom you have had difficulties in your life. May all beings everywhere be reconciled.

\section{VIPASSANA}

Vipassana is a word in the Pali language, one of the ancient languages of India along with Sanskrit. Sometimes Vipassana is translated as "insight meditation" because one of the main effects of the practice is that you get deep understandings about the nature of experience, the nature of yourself, the nature of deep issues-universal issues such as how it is that pain turns into suffering, how it is that pleasure either becomes satisfaction or becomes neediness, and how it is that the sense of self arises.
Vipassana meditation is also called "mindfulness meditation" because we are very attentive. The main technique is to become extraordinarily attentive to ordinary experience. Unfortunately, the word mindfulness can be a bit misleading if you interpret mindfulness to mean that you are constantly thinking about what you're doing. Mindful in the proper sense of the word means to be attentive and conscious about what's happening. The word "insight" can be a little misleading too because it's not only a word from Buddhism, but also is a word used in psychotherapy. When you do psychotherapy, you get insights. Of course, those insights are very important, but they are typically insights into your own personality, and the specific issues of your life. The insights that come because of Vipassana are deeper and more general than those that are ordinarily encountered in psychotherapy. They deal with very broad issues that are multiply rather than singularly applicable. In science, a deep theory augers many specific applications. Out of a single fundamental breakthrough in science you may have dozens--or even thousands--of specific applications. So, in the same way, the insights that come from Vipassana practice let us understand the very nature of personality itself, not just things about our own personality. So Vipassana is "insight" in the sense of deep insight and it is "mindfulness" in the sense of extraordinary attentiveness, it is applied to the inner world. The world of subjective experience: hearing, seeing, smelling, tasting, the feeling body and the thinking mind. They developed a science of these six senses and it's called Vipassana.

\section{EQUANIMITY :}

One such term is "equanimity." it does not mean a cooled out, passive or indifferent attitude. Rather, it means an attitude of not interfering with the operation of the six senses. If you have a sensation in your knee and it's painful and it wants to spread, you let it spread. Why? Because you 
discover that it is precisely the interference with that sensation that causes suffering, not the sensation itself. Equanimity literally means "balance." It means not to push and pull the flow of the senses. It does not for a moment imply that one would fail to act with respect to external circumstances, nor does it imply passivity, apathy or anything like that. Whenever one brings mindfulness and equanimity to ordinary experience, an evolutionary process takes place, consisting of two aspects. One aspect is insight and the other is purification. Let's talk about what we mean by purification. We all have within us sources of unhappiness. You notice that very quickly when you sit down to meditate. You'll feel just fine and then there will be something that will make your world less than perfect. You get sleepy, or your mind wanders, or this or that emotion comes up, negative tapes start to come up, traumatic memories appear, you feel angry, you want to jump out of your skin, you're running all sorts of fantasies, doing things to divert yourself, you're aware of inner conflicts. We are chock full of sources of unhappiness which are completely foreign to our being. It is not in the nature of consciousness to suffer. However, we have acquired certain limiting forces: cravings and aversions, painful memories, inappropriate yet habitual behaviour patterns, et cetera.

When we sit down and do this practice that's all going to come up. So, you don't always feel good while doing Vipassana meditation. In fact, you might feel lousy. I know some of you may want to leave the retreat right now having heard that. "I thought meditation is supposed to make a person feel great." Yes, in the long run, but an important aspect of meditation is to sit down and start working through the sources of not feeling great, whatever they may be. You literally eat your way through them, one after another, after another, after another. How? By just being mindful and having equanimity, that's all. Whatever comes up, you'll observe it and you'll do nothing. You'll be very aware and that's all.

\section{MINDFULNESS AND EQUANIMITY:}

Now that may seem trivial at best, stupid at worst. But it is quite powerful. Let's say that one of these blockages to happiness comes up as we meditate--a negative tape, a craving, an aversion, an inner conflict, a congealing. If we reject it and say "I don't want you," we're pushing it away. But to reject it we must "touch" it, by pushing on it. If on the other hand, we identify with it, buy into it and let it pull us away, then again, we've "touched" it. As soon as one touches it, one re-charges the energy supply of that negativity. If you try to push it away or pull it to you, any touch whatsoever means that this negativitycan "recharge its battery" as it were, from our general "pool of psychic energy." But if we don't touch it then it must play itself out on its own power source which is quite finite and if we continue to be alert and simply observe, eventually the intrinsic energy source of that negativity dissipates and it goes away forever. It gets worked through.

When sufficient mindfulness and equanimity are brought to bear on ordinary experience, we arrive at purification and insight. And, because of the purification and insight, our intrinsic happiness, our true birth right and spiritual reality, gets uncovered and we discover that what we thought was the world of phenomena--the world of time, space, and matter--turns out to really be a world of spiritual energy, and that we have direct contact with it moment by moment. Because, when the senses become purified, when the inner conflicts-at all levels--have been broken up, the flow of these ordinary senses turns into a prayer, a mantra, a sacred song, and we find that, just by living our life.Literally, Vipassana means "to clarify," "to see clearly," or "to perceive clearly"--Vi means "clearly." Vipassana means that the 
operation of the senses becomes clarified in the two meanings of the word "clarify." In one meaning of the word, when something is clarified that which was indistinct becomes distinct. The other meaning of the word clarify is that which was opaque becomes transparent. So in Vipassana we do nothing but try to be very distinct. To discern moment by moment what are the components of our experience.

Now let's talk a little more about insight. In Vipassana you get understandings into the most fundamental things by observing ourself very carefully. Here we have another analogy from science. When people observe under a microscope they start to discover things they could never see with the naked eye. There's no way to know that our bodies are made up of trillions of little cells. No matter how hard you look at your body, you'll never see them. But if you look under a microscope you will, and you'll understand something deep and fundamental about the nature of life. It's called the cell theory. It's the basis of modem biology and modem medicine. The microscope is an awareness extending tool that allows us to see something that is always there but not evident to the naked eye. Likewise, the mindfulness practice, the concentration practice that we will be developing here, is to the exploration of our internal world what the microscope is to the exploration of the external world. It's going to allow us to see finer levels of structure that are invisible to people otherwise, but are very important.

\section{NO SELF:}

Another facet of insights is related to a person's sense of self. There are true and useful to know about how one's sense of self arises moment by moment. We think there is a "thing" inside us called a self, but upon closer investigation we discover that there is an activity called personality that rises and passes as part of the effortless flow of nature. That activity called personality is made up of certain ideas and certain body sensations that moment by moment give us the sense that "I am." When those ideas and body sensations are greeted with complete awareness and zero interference, then we have a wonderful paradoxical experience. Obviously if you have complete awareness and zero interference with those ideas and body sensations that in this moment give you the sense "I am," then we would have to say that we are allowing your personality to completely express itself. On the other hand, whenever we have any experience and maintain continuous awareness and zero interference. The fully experienced self is a "doing" rather than a "thing" and hence is sometimes called "noself." Once we realize that, our sense of self becomes elastic like rubber, and we can expand and contract effortlessly with the flow of events. we can think of it as an elastic self which can get as big or as small as the circumstance requires, a bouncy and vibrant pure "doing" called personality. So, we can learn how to complete our personality and in learning that we also learn how to sometimes let go of our personality. An elastic self can get as big as the whole universe and therefore can encompass all things and it can get as small as zero and therefore know a state of true rest, real peace and security.

\section{Discussion : WHERE THE PATH LEADS:}

with this practice, we bring mindfulness (specificity of awareness) and equanimity (non-interfering with awareness) to ordinary experience. Thus, we get purification, which is a release of the blockages to happiness, and we get insight which is deep, many-faceted understanding into the nature of our experience. Because of this what happens? We become empowered, we become free. We have a sense of freedom that is not dependent on circumstances, we have a sense of happiness that is not dependent on conditions. 
One might say that through mindfulness meditation the old dirty paint is scraped off the walls of the soul and through daily loving kindness meditation a new beautiful coat is put on one layer at a time.

\section{CONCLUSION:}

Taking all there in to consideration it can be firmly said that Vipassana is a form of Buddhist derived meditation oriented towards delivering insight \& presence. Vipassana meditation delivers powerful levels of insight and presence and takes less time and easier to do. Main effect of the practice is that we get deep understanding about the nature of our self.
It brings inner peace ultimately which help to restore compatibility or harmony ultimately establish the stability Which is important for swasth.

\section{References:}

1. Charak Samhita

Pro.Vd.Y.G.Joshi,Vaidyamitra Prakashan, $2^{\text {nd }}$ Edition $8^{\text {th }}$ March 2005

2. Sushrut Samhita Anant Ram Sharma ,Chaukhamba Prakashan 2013 Edition.

3. www.dharma.org/en/art

\section{Cite this article:}

Innermost reconciliation through vipassana

Shweta C. Khade, Archana Gharge

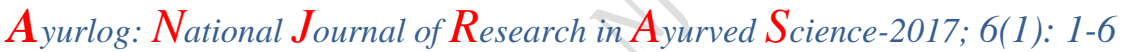

